\title{
Research on the Positive Correlation between the Degree of Self-Organization and the Effectiveness of Social Work Intervention in Elderly Care Institutions
}

\author{
Yaqin Hu, Qixuan Ying, Lan Yang, Wen Li, Lumu Man \\ Southwest Petroleum University, Chengdu, China \\ Email: hyq126hyq@126.com
}

How to cite this paper: Hu, Y.Q., Ying, Q.X., Yang, L., Li, W. and Man, L.M. (2019) Research on the Positive Correlation between the Degree of Self-Organization and the Effectiveness of Social Work Intervention in Elderly Care Institutions. Open Journal of Social Sciences, 7, 265-270. https://doi.org/10.4236/jss.2019.711019

Received: September 12, 2019

Accepted: November 22, 2019

Published: November 25, 2019

Copyright $\odot 2019$ by author(s) and Scientific Research Publishing Inc. This work is licensed under the Creative Commons Attribution International License (CC BY 4.0).

http://creativecommons.org/licenses/by/4.0/

\begin{abstract}
This paper compares the intervention degree and effectiveness of social worker intervention in general pension institutions and high-end pension institutions to explore the necessity and importance of it in the construction of elderly self-organization through comprehensive analysis of demand satisfaction, resource allocation, capacity-building and organizational structure, and draws a conclusion that the degree of elderly self-organization is positively related to the effectiveness of social workers intervention.
\end{abstract}

\section{Keywords}

Elderly Self-Organization, Intervention Effect of Social Workers, High-End Endowment

\section{Introduction}

At present, the high-end pension model has been rising in China's pension market. Different from the concept of "one bed" in traditional pension institutions, high-end pension institutions meet the needs of daily care, health management, culture and entertainment of the elderly through diversified services [1]. However, though high-end pension has supplemented China's pension market, China is still far from realizing the goal of active pension because of the lack of the service system, security system and management system of the pension market. The Plan of Action for the Development of Intelligent and Healthy Old-Age Industry points out that innovative services should be provided according to the needs of the elderly. Therefore, it is an important strategy 
to cultivate the elderly self-organization, meet the diversified needs of the elderly and promote them to participate in community governance to achieve the goal of active pension [2]. However, most of the elderly self-organization in China is still in its infancy, making it urgent for the professional to guide it. At present, some high-end pension institutions have introduced social workers to intervene in the elderly self-organization, and professionals to promote its development. This paper will discuss the intervention of social workers on the elderly self-organization in high-end pension institutions.

\section{Current Situation of the Self-Organization of the Elderly in China}

\subsection{Overview of the Self-Organization of the Elderly}

\subsubsection{Current Situation of the Self-Organization of the Elderly}

Self-organization is a kind of bottom-up organization, which is independent, voluntary and unofficial. Through the self-management and service of the elderly, the elderly self-organization can enhance their social communication, mobilize their initiative in community governance, and promote the healthy development of the community while enhancing their sense of belonging and self-worth. At present, most elderly self-organizations are geriatric associations. By the end of 2014, China's urban and rural community elderly associations had reached 490,000 , covering 74 percent [3]. Both communities and institutions have the emergence of elderly self-organization.

\subsubsection{Development Potential}

1) The lack of incentive mechanism and long-term sustainability. Due to the staff's low expectation on the elderly's ability value and the lack of perfect system guarantee, the individual's subjective intention has a great impact on mobilizing the elderly's enthusiasm [4].

2) The severe population limitations and narrow coverage. Staffs only focus on the elderly who are healthy and secured while ignore the others. Traditional perceptions of gender roles also limit the participation of members of different genders.

3) The phenomenon of capable person and the concentration of power are prominent [5]. In the early stage of self-organization construction, we need "capable person" with appeal to lay a foundation. If there is no smooth transition of power distribution in the middle period of construction, it will easily lead to power concentration and internal disharmony.

4) The lack of bottom-up institutional guarantee. Due to the far-reaching influence of bureaucracy in management, it is difficult to change the unequal relationship between management and self-organization. Most self-organizations lack efficient communication channels and sufficient democracy in upward interaction. Their independence is diluted and they are forced to face vertical subordination [2]. 


\subsection{Overview of Self-Organization for the Elderly in High-End Pension Institutions: A Case of T Pension Institution}

\subsubsection{Background of $T$ Pension Institution}

$\mathrm{T}$ institution is characterized by large-scale, full-function and combination of medical and nursing services to meet the health, safety, social and cultural needs of the elderly and create a high-quality life for the elderly. There are residential apartments, independent hospitals and various activity rooms, supplemented by a complete service system. At present, $\mathrm{T}$ institution has put into operation four parks and built eight medical care communities, with the total number of service households exceeding 100 million.

\subsubsection{Necessity and Feasibility Analysis of Social Worker Intervention in T Institution}

As analyzed above, self-organization of the elderly has many problems in the initial stage and needs the intervention and guidance of professionals. The goals of social work are "to satisfy the internal needs of individuals more fully and develop the functional performance of individual social relations", which is consistent with the goals of elderly self-organization [6]. In addition, research shows that high-income elderly people are more likely to become volunteers [7], the elderly in $\mathrm{T}$ institution have high educational and high income whose participation in the activities of the institution is not satisfied with simple passive participation, resulting in the need of improvement of the organization of the activities.

\subsubsection{Overview of Self-Organization for the Elderly in T Institutions}

The elderly self-organization of $\mathrm{T}$ is mainly divided into living area self-organization and activity area self-organization, which shows the characteristics of full participation, high enthusiasm and strong personality, and gradually develops towards equality and autonomy.

The self-organization of living area mainly mediates the contradiction of the elderly life and promotes communication and understanding between the upper and lower levels. The elderly elect floor leaders independently to collect their opinions and feedback to the staff in time. This arrangement has greatly aroused the initiative of the elderly to participate in community construction.

The self-organization of activity area is divided into two parts: education for the aged and clubs, in which the elderly teach, rehearse and participate in performances independently, so as to enrich the spiritual and cultural life of the elderly, explore their potential ability and promote the re-development of the elderly. This kind of self-organization has a very perfect operation system, which basically realizes equal dialogue with the management and develops with the instituion itself.

As we can see, there are a large number of elderly self-organizations in the $\mathrm{T}$ institution, with different types and uneven development level. The whole organization is in the middle stage of smooth operation. Through the development of the elderly's self-ability and the improvement of the self-organization operation system by social workers, some organizations have achieved self-feeding, 
with a clear development plan, considerable independence and autonomy. Others have begun to take shape, the cadres have a clear sense of responsibility, the members have cohesion, and the self-organization expands steadily under the guidance of social workers.

\section{Comparative Analysis of Social Worker Intervention in Ordinary Institutions and T Institution}

Through further comparative analysis, we find that there are four main differences between ordinary institutions and $\mathrm{T}$ institution: demand satisfaction, capacity building, resource allocation and organizational structure construction. The first two points are about the development of the elderly, and the last two points are about the construction of the elderly self-organization. The comparison is shown in Table 1.

\section{Conclusions}

1) The degree of the elderly self-organization is positively correlated with the degree of social workers' intervention.

Through literature review, and empirical study, this paper concludes that the degree of elderly self-organization is positively correlated with the degree of social worker intervention.

By comparison, we find that most ordinary institutions are not equipped with professional social workers, and their degree of self-organization remains at the initial stage with low independence, autonomy and initiative. The role of elderly self-organization is mainly to solve basic needs and meet the administrative management of the institutions. Under the deep intervention of social workers, most of the elderly self-organizations of $\mathrm{T}$ institution have the conditions of independent development. Some of them are even in the middle stage of steady development of independent operation. The goal of mutual promotion between the elderly self-organization and the institution has been preliminarily completed, which meets the low-level physiological and social needs of the elderly and gradually develops the sense of personal worth.

2) Suggestions on measures to promote the coordination of the elderly self-organization and social work intervention are as follow.

a) Explore the resources of the elderly, pay attention to the personalized appeal of the elderly, and realize the common growth of self-organization members.

The purpose of group work is to promote individual growth according to individual abilities and needs, to adapt individuals to other people, groups and society, to motivate individuals to improve their society, and to make everyone realize their rights, abilities and uniqueness [9]. It is found that the elderly have a lot of potential for learning new knowledge [10]. Social workers should actively tap the inner potential of the elderly, guide the elderly self-organization to expand its connotation, such as art, current affairs and so on. Social workers 
Table 1. Comparative analysis of social worker involvement in ordinary institutions and T institution.

\begin{tabular}{|c|c|c|c|c|}
\hline \multirow{2}{*}{$\begin{array}{c}\text { Interventional } \\
\text { Aspects }\end{array}$} & \multicolumn{2}{|c|}{ Ordinary Institutions } & \multicolumn{2}{|c|}{ T Institution } \\
\hline & Degree of Intervention & Utility & Degree of Intervention & Utility \\
\hline $\begin{array}{l}\text { Demand } \\
\text { Satisfaction }\end{array}$ & $\begin{array}{l}\text { 1) Stay on the surface } \\
\text { 2) Unified }\end{array}$ & $\begin{array}{l}\text { Meet only basic survival } \\
\text { needs }\end{array}$ & $\begin{array}{l}\text { 1) Establish demand files to keep } \\
\text { abreast of demand } \\
\text { 2) Provide individualized service } \\
\text { for different old people }\end{array}$ & $\begin{array}{l}\text { 1) Meet individualized needs } \\
\text { 2) Break crowd limitations } \\
\text { 3) Expand the connotation of } \\
\text { self-organization }\end{array}$ \\
\hline $\begin{array}{l}\text { Resource } \\
\text { Allocation }\end{array}$ & $\begin{array}{l}\text { 1) Link the "visual" } \\
\text { resources inside and } \\
\text { outside institutions } \\
\text { 2) Increase resource } \\
\text { utilization }\end{array}$ & $\begin{array}{l}\text { 1) Integrate community } \\
\text { resources } \\
\text { 2) Expand self-organization } \\
\text { development channels }\end{array}$ & $\begin{array}{l}\text { 1) Link various resources to enrich } \\
\text { institutional activities } \\
\text { 2) Break away from the traditional } \\
\text { pessimistic thinking, develop the } \\
\text { elderly's resources, and establish } \\
\text { incentive mechanism to ensure the } \\
\text { initiation }\end{array}$ & $\begin{array}{l}\text { 1) Reduce labor costs } \\
\text { 2) Enhance the elderly's sense of } \\
\text { self-efficacy and promote their } \\
\text { participation in institutional } \\
\text { governance }\end{array}$ \\
\hline $\begin{array}{l}\text { Capacity } \\
\text { Building }\end{array}$ & $\begin{array}{l}\text { Focus on training } \\
\text { practical skills and } \\
\text { building volunteer } \\
\text { organizations }\end{array}$ & $\begin{array}{l}\text { Enhance building ability } \\
\text { and advocate elderly's } \\
\text { participation in community } \\
\text { development }\end{array}$ & $\begin{array}{l}\text { 1) Develop leadership skills and } \\
\text { work skills } \\
\text { 2) Balance the distribution of rights } \\
\text { and adjust the atmosphere of } \\
\text { relations by one-on-one } \\
\text { conversations and other ways to } \\
\text { eliminate the phenomenon of } \\
\text { capacity person }\end{array}$ & $\begin{array}{l}\text { 1) Promote self-development of the } \\
\text { elderly } \\
\text { 2) Coordinate the internal relations } \\
\text { of self-organization } \\
\text { 3) Promote sustainable development }\end{array}$ \\
\hline $\begin{array}{l}\text { Organization } \\
\text { Structure }\end{array}$ & $\begin{array}{l}\text { Intervene in up-low } \\
\text { information } \\
\text { transmission and } \\
\text { management policies }\end{array}$ & $\begin{array}{l}\text { 1) Influence government } \\
\text { and institutional policies } \\
\text { 2) Provide institutional } \\
\text { guarantee [8] }\end{array}$ & $\begin{array}{l}\text { Provide institutional support in } \\
\text { terms of communication, operation } \\
\text { system and development model }\end{array}$ & $\begin{array}{l}\text { Influence institutional policy } \\
\text { decisions to create a good and relaxed } \\
\text { environment for self-organization }\end{array}$ \\
\hline
\end{tabular}

should combine the different characteristics of the target group, establish multi-type self-organization, guide the active participation of the elderly, and improve the self-efficacy of the elderly while meeting their various needs.

b) Coordinate the internal relationship of self-organization with humanistic concern.

The interpersonal environment in self-organization is an important factor for sustainable development. Social workers can balance the distribution of rights among self-organizing members by establishing a perfect system and timely mediate the conflicts among members through case management and group activities to enhance mutual understanding and cohesion.

3) Extend the external communication channels of the elderly self-organization and provide macro-institutional guarantee.

Social workers can build a relatively relaxed and equal environment for the development of the elderly self-organization by expanding communication channels, improving the elderly's ability to express their needs, and influencing institutional policy decisions. Among them, social workers can link the relevant departments inside and outside the community and expand the channels of information circulation, which can greatly improve the communication efficiency between the elderly self-organization and management. 
Elderly self-organization is one of the important ways to alleviate the pressure of pension in China. The development of this form urgently needs the guidance and support of professionals. In addition to the service staff should improve their own service level; the government should also expand channels for the introduction of social workers and other professionals in the pension industry. Through policy guidance, the government can vigorously promote the professionalization and humanization of the pension level, to achieve the social goal of active pension.

\section{Conflicts of Interest}

The authors declare no conflicts of interest regarding the publication of this paper.

\section{References}

[1] Xiong, Z.J. (2015) A Study on the Influencing Factors of High-End Pension Consumption Willingness of Elderly Consumers. Zhejiang Gongshang University, Hangzhou.

[2] Hong, L. (2011) Reflections on Self-Organization of Elderly Women in Community: A Case Study of a Group of Elderly Women. Master, 23, 113.

[3] Qiang, Z. (2018) Helping the Aged by the Aged: A Study on the Participation of the Aged Association in the Practice of Home-Based Old-Age Care in Urban Communities: A Case Study of W Association for the Aged in Wuhan. Northwest Population Journal, 39, 91-99.

[4] Ouyang, Z.M., Ge, X.T. and Yang, Y.Y. (2018) A Case Study of China and Australia Aged University-A Case Study of NC Aged University and BC Third Age University. Modern Distance Education, 1, 57-65.

[5] Yao, X.Y. (2015) Self-Organization of the Elderly in Community Care and Social Work Intervention. Soochow University, Soochow.

[6] Hollis, F. (1972) Casework: A Psychosocial Therapy. Random House, New York, 9.

[7] Warburton, J. and Stirling, C. (2007) Factors Affecting Volunteering Among Older Rural and City Dwelling Adults in Australia. Educational Gerontology, 33, 23-43. https://doi.org/10.1080/03601270600846824

[8] Yang, G.H. and Wang, R.H. (2010) Social Work and Community Self-Organization Capacity Building. Scientific Socialism, No. 2, 114-117.

[9] Wang, S.B. (2006) Introduction to Social Work. 2nd Edition, Higher Education Press, Beijing, 122.

[10] Boulton-Lewis, G.M. (2010) Education and Learning for the Elderly: Why, How, What. Educational Gerontology, 36, 213-228. https://doi.org/10.1080/03601270903182877 